\title{
Invasion of a xeric forest by an exotic tree species in Argentina: Impacts on the diversity of arbuscular mycorrhizal fungi and pre-existing mutualistic relationships
}

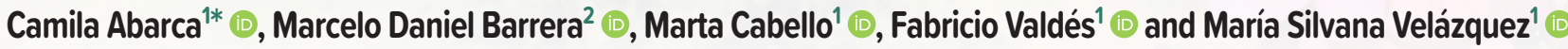

Received: March 13, 2020

Accepted: October 22, 2020

\begin{abstract}
This study aimed to analyse the effects of invasion by the exotic Ligustrum lucidum on mycorrhizal associations in forests of Celtis tala, and to determine the role that these fungi play in the invasion process. We analyzed colonization and response to mycorrhization of both plant species under greenhouse conditions after inoculation with soil obtained from patches of non-invaded native forests and invaded forests. The spores present in pots at the end of the experiment were counted and identified. Colonization of L. lucidum was greater in plants inoculated with invaded forest soil, whereas colonization of $C$. tala was greater in plants inoculated with non-invaded native forest soil. Principal component analysis of fungal species abundance showed differences in AMF composition according to host plant and forest type. The results show that L. lucidum establishes symbiosis with native AMF, which triggers changes in community structure. These changes favored the mycorrhization of L. lucidum and interfered with the mycorrhization of $C$. tala. AMF may have either a direct or indirect role in the invasion process, not only benefiting the invasive species but also preventing the regeneration of native plants.
\end{abstract}

Keywords: biological invasion, Glomeromycota, mycorrhizal colonization, xeric forest, Celtis tala, Ligustrum lucidum

\section{Introduction}

Biological invasions are one of the most important ecological disturbances. Invasive exotic plants can trigger multiple impacts on the ecosystems in which they are established, modifying the structure and dynamics of the native communities, the nutrient cycles, and the relationships between ecosystem components (Wang et al. 2016). Although these effects have been extensively documented, the operating mechanisms are still poorly understood.
The impact generated by an exotic plant on the microbial community of the rhizosphere may act as a factor for its invasion success (Xiao et al. 2014; Piper et al. 2015). The arbuscular mycorrhizal fungi (AMF, phylum Glomeromycota) are obligate biotrophs found in the rhizosphere of all terrestrial ecosystems, and they colonize the roots of $75 \%$ of plant species (Brundrett 2009). The association of plants with AMF may be a key factor in the composition and other structural components of plant communities due to the wide variety of positive, neutral, or negative responses of different plant species to symbiosis (Klironomos et al. 2011).

1 Instituto de Botánica Spegazzini, Universidad Nacional de la Plata, 1900, La Plata, BA, Argentina

2 Laboratorio de Investigación de Sistemas Ecológicos y Ambientales, Universidad Nacional de la Plata, 1900, La Plata, BA, Argentina

* Corresponding author: camila.abrc@gmail.com 
For this reason, the role of AMF in the establishment of exotic plants has been widely documented.

The mechanisms that drive AMF and invasive plant interactions are not completely clear yet. It has been observed that invasive plant species tend to associate with cosmopolitan AMF species or to form novel associations in their exotic ranges (Núñez \& Dickie 2014). Zhang et al. (2010) found that the invasive forb Solidago canadensis alters soil AMF community composition because of a fungal-host preference, increasing some AMF species while reducing others. Checinska et al. (2019) performed a greenhouse experiment with native and exotic grasses and forbs and found that invasive species showed greater colonization percentages than native species. In this study, AM colonization was not positively correlated with performance in the field for exotic species, while native species showed a positive correlation between colonization and biomass and dominance. In this way, although exotic species may not depend on AMF to establish, they still can greatly affect native species by modifying or degrading AMF communities.

In this study, we evaluated the colonization rates and response to mycorrhization during the early stages of development of Celtis tala, commonly known as "tala", and Ligustrum lucidum. The tala tree is native to America, and it grows naturally in northwestern Buenos Aires province, Argentina, forming xeric forests named "talares". These talares are currently degraded by the presence and rapid expansion of L. lucidum, a tree of Chinese origin that has invaded many regions worldwide, including various forests in Argentina (Dascanio \& Ricci 1988; Dascanio et al. 1994; Zamora Nasca et al. 2014).

This study aimed to analyze the effect that the expansion of $L$. lucidum has on the mycorrhizal associations already established in C. tala forests and to determine the role that AMF play in the invasion process. We hypothesized that L. lucidum would have the ability to establish symbiosis with some of the native AMF species and that its expansion would lead to changes in the fungal community, modifying the preexistent mutualisms between native plant species and fungi.

\section{Materials and methods}

\section{Study site}

Samples were taken at El Destino ( $35^{\circ} 1^{\prime}$ S, $\left.57^{\circ} 17^{\prime} \mathrm{W}\right)$, a natural area belonging to "Parque Costero del Sur" Biosphere Reserve, located between the towns of Magdalena and Punta Indio, Buenos Aires province, Argentina. The climate is warm-temperate with a mean annual temperature of $15{ }^{\circ} \mathrm{C}$, the highest maximum mean exceeding $22^{\circ} \mathrm{C}$ in January and the lowest minimum mean being below $10^{\circ} \mathrm{C}$ in August. The annual rainfall averages $97 \mathrm{~cm}$, with two minima (ca. $6 \mathrm{~cm}$ ) at the end of winter (August) and in midsummer (January) (Vervoorst 1967). The talares are restricted to the shore-banks deposited by the Platense marine transgression, consisting of a subsoil formed by shells of marine invertebrates and shallow sandy-humic soil. It is classified as a 'Typic Rendoll' or 'rendzina' (Vargas Gil et al. 1972; Sánchez et al. 1976).

Soil used as inoculum of AMF and seeds were collected from cords that have a tree structure with a spatial gradient in the proportion of L. lucidum W.T. Aiton (Oleaceae). Along this gradient, we established the sampling units: forest patches with native vegetation of Celtis tala Gill. ex Planch (Celtidaceae), Scutia buxifolia, and Jodinha rhombifolia (Hook. \& Arn.) Reissek 1861 (NAT= non-invaded native forest soil) and from patches completely invaded by L. lucidum without native trees (INV=invaded forest soil), located 50 meters from the patch boundary. Three $100 \mathrm{~m}$ transects were established parallel to each other and approximately 500 $\mathrm{m}$ apart, at the ends of which both contrasting situations were located. Forty-five soil samples (15 subsamples from each site) were taken randomly from three representative sites of each situation (NAT and INV) and combined to form composite inocula. The soil samples were taken from forest soil and not only from L. lucidum and C. tala rhizosphere to obtain representative samples of the AMF community present in both contrasting situations. Seeds were collected randomly from litter at the sampling spots.

\section{Greenhouse experiment}

The experiment was performed from May to October 2018, under greenhouse conditions at "Instituto de Botánica Spegazzini" UNLP, La Plata, Argentina. The seeds of C. tala and L. lucidum were germinated in a mixture of perlite: vermiculite: terrafertil ${ }^{\circledR}$ (1:1:3) previously tyndalized (steamed for 30 minutes on three successive days). Three weeks after germination, seedlings of uniform size were selected, randomly transplanted to $3 \mathrm{~L}$ pots containing $2.5 \mathrm{~L}$ of the same substrate described above, and inoculated with $100 \mathrm{~g} / \mathrm{dry}$ soil from the NAT and INV forest patches. Each pot contained a single plant. Plants grew under controlled temperature $\left(20-25^{\circ} \mathrm{C}\right)$, photoperiod $(8 / 16 \mathrm{~h}$ day/night), and humidity (40-60\%) and were watered once a week with filtered water.

To suppress AMF colonization in control treatments, we used a commercial fungicide with Benomyl (50 mg of Benomyl in $100 \mathrm{ml}$ of filtered water per $1 \mathrm{~kg}$ of substrate) (Koorem et al. 2012). This fungicide suppresses different types of rhizospheric fungi (e.g. pathogens, dark septate endophytes) and has been successfully used in numerous studies (Grilli et al. 2014). No signs of pathogenic fungi were found in non-treated plants. Therefore, we consider that the absence of AMF was the main effect of the fungicide, as frequently observed in this type of analysis (Gross et al. 2010; McCain et al. 2011; Deguchi et al. 2012). The fungicide was applied in AMF-pots at the beginning of the experiment and every three weeks until the end of the experiment (Gross et al. 2010). 
The experiment consisted of five replicates $\mathrm{x}$ two species (C. tala, L. lucidum) $\mathrm{x}$ two treatments with fungicide (AMF+, AMF-) $x$ two inoculum sources (NAT, INV). The 40 plants used in the experiment grew under greenhouse-controlled conditions and were rotated periodically to avoid spatial and environmental differences. After six months, we removed the plants from the pots and washed the roots carefully to avoid damage.

\section{Mycorrhizal colonization}

We evaluated the mycorrhizal colonization of 40 plants by staining fragments of fine roots in good conditions, following the methodology described by Phillips \& Hayman (1970). The colonization percentages were calculated according to the segments method described by Cabello et al. (2013). We analyzed the presence of external mycelium (EM) (hyphae attached to the external surface of the roots), internal mycelium (IM), entry points (EP), arbuscules (Ar), vesicles (Ve), and coils (Co).

\section{Growth parameters}

At the end of the experiment, we measured the vegetative growth parameters of the plants. In each plant, the stem (SL) and root lengths (RL) were measured from the base to the apical meristems using a meter. The aerial and radical structures were oven-dried at $60^{\circ} \mathrm{C}$ until constant weight and weighed to obtain the dry biomass (B).

The "mycorrhizal dependence index" (MD) was calculated using the $B$ values, following the formula: $M D=\left(\left[B_{\text {inoculated plants }}\right.\right.$ - $\left.\mathrm{B}_{\text {non-inoculated plants }}\right]$ / $\mathrm{B}_{\text {inoculated plants }}$ ) x 100.

\section{Counting and identification of AMF spores}

The isolation of the AMF spores present in the rhizospheric soil of each pot was performed by wet sieving and decanting of $100 \mathrm{~g}$ of soil using sieves of different mesh sizes $(450,105,75,30 \mu \mathrm{m})$ (Gerdemann \& Nicolson 1973), followed by sucrose gradient centrifugation (Walker et al. 1982). Spore identification followed the descriptions of the International Culture Collection of Arbuscular and Vesicular-Arbuscular Mycorrhizal Fungi (INVAM, USA, http://invam.cafwvu.edu) and Błaszkowski (2012). The assignment of AMF morphotypes to families and genera followed the consensus classification of AMF phylogeny (www.amf-phylogeny.com). In each sample, we determined the spore density (spore number in $100 \mathrm{~g}$ of dry soil) and relative abundance (ni/N) of each species. For each pot species, richness $(S)$ and diversity indices were calculated.

\section{Data analysis}

The non-parametric Kruskal-Wallis test was used to analyze the colonization percentages between treatments. The growth parameters were compared with a bifactorial ANOVA, considering the use of fungicide (AMF+, $\mathrm{AMF}-$ ) and source of inoculum (NAT, INV) as factors. The normality and homoscedasticity of variances were verified with ShapiroWilk's and Levene's tests. A Tukey test was used to identify differences between means.

We carried out a principal component analysis (PCA) with the AMF species relative abundance to explore differences between treatments. Data were transformed to $\log (\mathrm{x}+1)$ and Bray-Curtis was used as a distance measure. The values of spore density, specific richness (S), and diversity indices were subjected to a bifactorial ANOVA considering the plant species and source of inoculum as factors. The normality and homoscedasticity of variances were verified with Shapiro-Wilk's and Levene's tests. A Tukey test was used to identify differences between means. Since we did not find spores in good condition in the AMF pots, we did not include them in the analyses.

All statistical analyses were carried out using InfoStat version 2016 (Di Rienzo et al. 2016) and PC-ORD 6.0 (McCune \& Mefford 2006), with $\alpha=0.05$.

\section{Results}

\section{Colonization}

Both species showed colonization by AMF and all the characteristic structures of the mycorrhizal activity, except for coils in the roots of $C$. tala (Fig. 1). The use of fungicide considerably reduced the mycorrhizal colonization of the roots of both species. Plants without fungicide showed total colonization ranging between $25 \%$ and $95 \%$, whereas those treated with fungicide had less than $10 \%$ colonization.

The total colonization of the invasive L. lucidum was greater in plants inoculated with invaded forest soil ( $h=13.36, p=0.0037)$. In C. tala, the total colonization percentages were higher in plants inoculated with noninvaded native forest soil, although the differences were not significant ( $\mathrm{h}=7.70, \mathrm{p}=0.0502)$. In L. lucidum, all fungal structures showed differences between treatments, whereas in C. tala only the percentages of EP and Ar differed ( $\mathrm{p}<0.05)$. Interaction between factors was not significant in all cases, except for IM in L. lucidum

\section{Growth parameters and mycorrhizal dependence}

The root length of $C$. tala was the only growth parameter that showed significant differences between treatments, being higher in the pots inoculated with INV soil $(f=12.37$, $\mathrm{p}=0.0066)$. The effect of the fungicide was not significant ( $p$ > 0.05) (Tab. 1). With regard to the MD index, the only negative value was observed in plants of $C$. tala inoculated with INV soil. In the other treatments, the index yielded positive values. Positive values indicate that mycorrhizal colonization is associated with higher biomass in the host plant, while negative values indicate that mycorrhization affects growth negatively. 

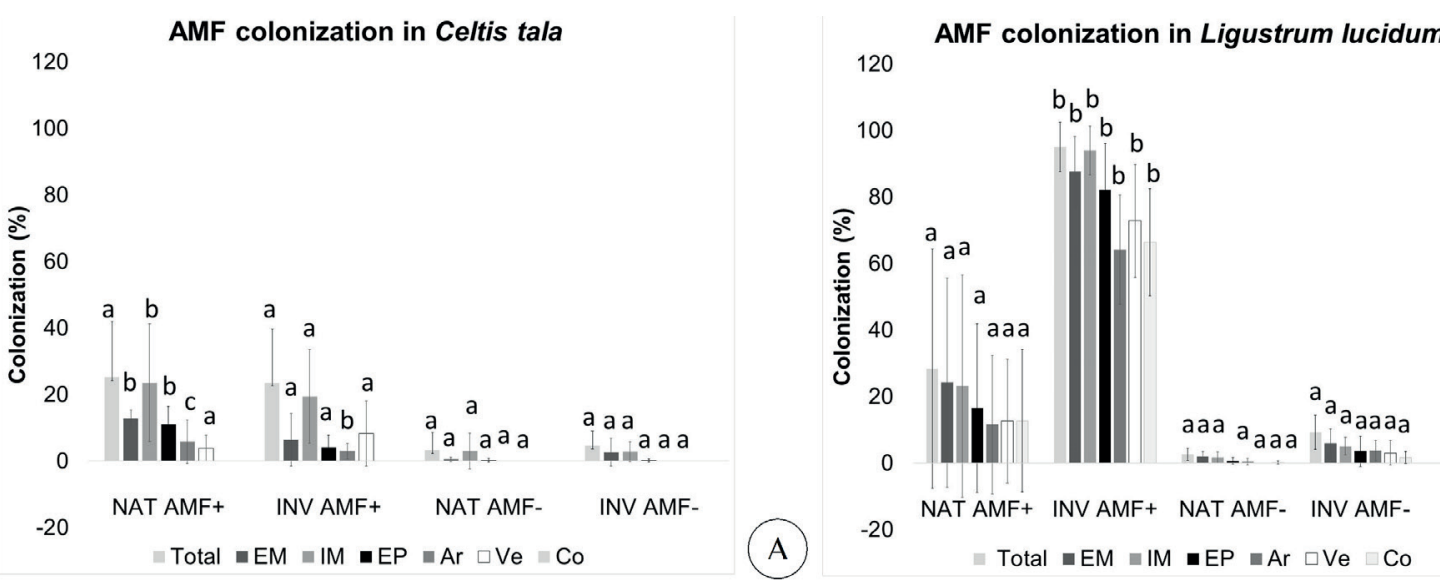

Figure 1. Percentages of external mycelium (EM), internal mycelium (IM), entry points (EP), arbuscules (Ar), vesicles (Ve), coils (Co) and total mycorrhizal colonization in roots of Celtis tala $(\mathbf{A})$ and Ligustrum lucidum $(\mathbf{B})$ inoculated with non-invaded native forest soil (untreated: NAT AMF+; treated with fungicide: NAT AMF-) and with invaded forest soil (untreated: INV AMF+; treated with fungicide: INV AMF-). Different letters indicate statistical difference among percentages (Tukey's test, $\mathrm{p}<0.05$ ).

Table 1. Mean and standard deviation of growth parameters and mycorrhizal dependence (MD) of Celtis tala and Ligustrum lucidum inoculated with non-invaded native forest soil (untreated: NAT AMF+; treated with fungicide: NAT AMF-) and with invaded forest soil (untreated: INV AMF+; treated with fungicide: INV AMF-). Means followed by a different letter are significantly different (Tukey's test, $\mathrm{p}<0.05)$. Two-way ANOVA results: $\mathrm{ns}=$ non significant, ${ }^{*}=\mathrm{p}<0.05,{ }^{* *}=\mathrm{p}<0.01,{ }^{* * *}=\mathrm{p}<0.001$.

\begin{tabular}{|c|c|c|c|c|c|}
\hline Celtis tala & & Stem length $(\mathrm{cm})$ & Root length $(\mathrm{cm})$ & Biomass (g) & MD \\
\hline \multirow{2}{*}{ NAT } & $\mathrm{AMF}+$ & $13.49 \pm 3.30$ & $8.56 \pm 3.26$ & $20.36 \pm 5.91$ & \multirow{2}{*}{0.19} \\
\hline & AMF- & $11.67 \pm 1.86$ & $4.8 \pm 0.72$ & $16.46 \pm 2.57$ & \\
\hline \multirow{2}{*}{ INV } & $\mathrm{AMF}+$ & $10.97 \pm 5.81$ & $5.19 \pm 2.21$ & $16.15 \pm 7.90$ & \multirow{2}{*}{-0.41} \\
\hline & AMF- & $14.77 \pm 5.02$ & $6.64 \pm 1.85$ & $22.81 \pm 6.86$ & \\
\hline \multicolumn{6}{|c|}{ ANOVA results } \\
\hline \multicolumn{2}{|c|}{ inoculum source } & ns & ns & ns & \\
\hline \multicolumn{2}{|c|}{ fungicide } & ns & ns & ns & \\
\hline \multicolumn{2}{|c|}{ inoculum source*fungicide } & ns & $*$ & ns & \\
\hline Ligsutum Iucidum & & Stem length $(\mathrm{cm})$ & Root length $(\mathrm{cm})$ & Biomass (g) & MD \\
\hline \multirow{2}{*}{ NAT } & $\mathrm{AMF}+$ & $84.90 \pm 11.36$ & $33.20 \pm 3.70$ & $27.02 \pm 5.33$ & \multirow{2}{*}{0.03} \\
\hline & AMF- & $102.00 \pm 8.60$ & $38.20 \pm 9.01$ & $26.24 \pm 1.98$ & \\
\hline \multirow{2}{*}{ INV } & $\mathrm{AMF}+$ & $81.88 \pm 8.78$ & $38.25 \pm 4.86$ & $28.6 \pm 4.03$ & \multirow{2}{*}{0.17} \\
\hline & AMF- & $87.20 \pm 18.02$ & $34.60 \pm 3.58$ & $23.4 \pm 5.00$ & \\
\hline \multicolumn{6}{|c|}{ ANOVA results } \\
\hline \multicolumn{2}{|c|}{ inoculum source } & ns & ns & ns & \\
\hline \multicolumn{2}{|c|}{ fungicide } & ns & ns & ns & \\
\hline \multicolumn{2}{|c|}{ inoculum source*fungicide } & ns & ns & ns & \\
\hline
\end{tabular}

\section{Counting and identification of AMF spores}

In the NAT inoculum, we identified spores of Diversispora spurca, Glomus sp., Pacispora sp.1, Sclerocystis sinuosa, Entrophospora infrequens, Acaulospora delicata, and Scutellospora cerradensis, whereas in INV, we found Diversispora spurca, Glomus sp., Claroideoglomus etunicatum, Glomus aggregatum, Rhizophagus intraradices, and Sclerocystis sinuosa.

After the bioassay, we identified 12 morphospecies of Glomeromycota belonging to the families Acaulosporaceae, Claroideoglomeraceae, Diversisporaceae, Glomeraceae, Pacisporaceae, and Gigasporaceae. As shown in Table 2, A. delicata was recovered in all treatments. The density of spores showed no significant differences between treatments ( $p>0.05)$. The specific richness ( $S$ ) was affected by both the inoculum source and the host species, being higher in C. tala than in L. lucidum and in NAT than in INV soil. The evenness (E) and diversity indices ( $\mathrm{H}^{\prime}$ and $\mathrm{D}$ ) were higher in C. tala and showed no significant differences between NAT and INV soils (Tab. 3).

The first two axes of the PCA (Fig. 2) explained $49.99 \%$ of the total variation of AMF species relative abundance and separated two sets of samples with no overlap corresponding to the pots of C. tala and L. lucidum. Considering Axis 3, the total variation explained by the first three axes was $64.38 \%$, and samples were grouped according to the source of inoculum (i.e., non-invaded native and invaded forest soil). It is important to note that $C$. tala samples showed a greater variation, while those of $L$. lucidum were grouped together at a close distance, indicating a high similarity between them. 
Table 2. Species of Glomeromycota recovered at the end of the experiment from Celtis tala and Ligustrum lucidum pots inoculated with non-indaved native (NAT) and invaded (INV) forest soil.

\begin{tabular}{|c|c|c|c|c|}
\hline \multirow{2}{*}{} & \multicolumn{2}{|c|}{ Celtis tala } & \multicolumn{2}{c|}{ Ligustrum lucidum } \\
\cline { 2 - 5 } & NAT & INV & NAT & INV \\
\hline Acaulospora delicata & $\mathrm{x}$ & $\mathrm{x}$ & $\mathrm{x}$ & $\mathrm{x}$ \\
\hline Acaulospora sp. & $\mathrm{x}$ & 0 & 0 & 0 \\
\hline Claroideoglomus claroideum & $\mathrm{x}$ & 0 & 0 & 0 \\
\hline Claroideoglomus etunicatum & 0 & 0 & $\mathrm{x}$ & 0 \\
\hline Diversispora spurca & $\mathrm{x}$ & 0 & 0 & 0 \\
\hline Funneliformis coronatum & $\mathrm{x}$ & 0 & 0 & 0 \\
\hline Glomus sp. & 0 & 0 & $\mathrm{x}$ & $\mathrm{x}$ \\
\hline Pacispora sp.1 & $\mathrm{x}$ & 0 & 0 & 0 \\
\hline Pacispora sp. 2 & 0 & $\mathrm{x}$ & 0 & 0 \\
\hline Sclerocystis sinuosa & 0 & $\mathrm{x}$ & 0 & 0 \\
\hline Scutellospora sp. & 0 & $\mathrm{x}$ & 0 & 0 \\
\hline Septoglomus constrictum & 0 & $\mathrm{x}$ & 0 & 0 \\
\hline
\end{tabular}

\section{Discussion}

We verified that AMF colonized both C. tala and $L$. lucidum. Velázquez (2011) and Irrazabal (2007) previously registered both species as hosts of these fungi under field conditions. Both species had the highest colonization percentages when they received, as a source of inoculum, soil from the forest where they were dominant in structure. Our results may indicate that $L$. lucidum has the ability to establish symbiosis with the native AMF during the early stages of invasion, as observed in plants inoculated with NAT soil, triggering changes in the microbiota that maximize the colonization rates, as observed in plants inoculated with INV soil. Zubek et al. (2016) showed that when an exotic plant is able to benefit from the association with native AMF, it tends to modify the relative abundance of the resident fungal species. Consequently, it interferes with the pre-existing mutualism relationships and negatively affects native plants by decreasing the available resources and the diversity of the soil microbiota.

In this study, C. tala showed the highest colonization in the presence of inoculum from the non-invaded native forest soil. This difference was significant in the case of entry points and arbuscules, which are structures cited as indicators of functional symbiosis (Smith \& Read 2008). The changes in the soil microbiota induced by the invasion of L. lucidum mentioned above could explain the low percentages of colonization observed in C. tala plants inoculated with

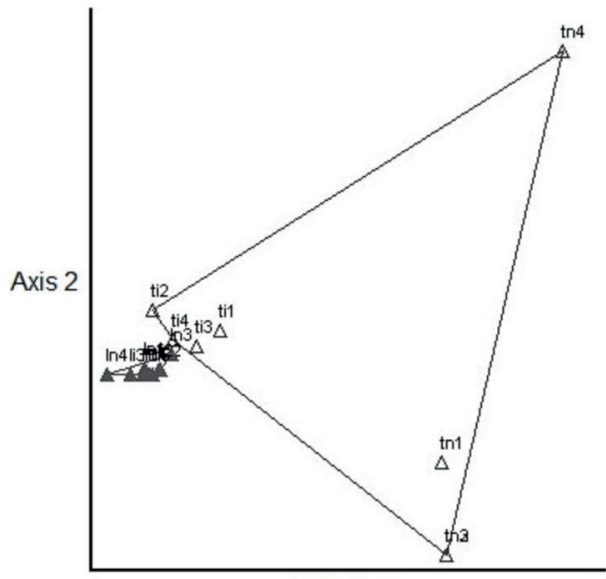

Axis 1 $\triangle$ C. tala

A. Lucidum

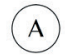

Figure 2. Principal Component Analysis (PCA) of the abundance of AMF species recovered from the pots. Axis 1 and 2, showing the distribution of the samples according to host species (Celtis tala and Ligustrum lucidum) (A). Axis 1 and 3, showing the distribution of the samples according to inoculum source (non-invaded native and invaded forest soil) (B).

Table 3. Mean and standard deviation of the number of Glomeromycota spores in $100 \mathrm{~g}$ of dry soil (spore density), specific richness $(\mathrm{S})$, evenness (E), Shannon-Wiener diversity index $\left(\mathrm{H}^{\prime}\right)$ and Simpson diversity index (D) from pots of Celtis tala and Ligustrum lucidum inoculated with the non-invaded native and invaded forest soil. Means followed by a different letter are significantly different (Tukey's test, $\mathrm{p}<0.05)$. Two-way ANOVA results: $\mathrm{ns}=$ non significant, ${ }^{*}=\mathrm{p}<0.05,{ }^{* *}=\mathrm{p}<0.01,{ }^{* * *}=\mathrm{p}<0.001$.

\begin{tabular}{|c|c|c|c|c|c|c|}
\hline & & Spore density (spores $/ 100 \mathrm{~g}$ of soil) & $\mathbf{S}$ & E & $\mathbf{H}^{\prime}$ & D \\
\hline \multirow{2}{*}{ Celtis tala } & NAT & $28 \pm 4.76^{a}$ & $5.5 \pm 0.57^{c}$ & $0.86 \pm 0.06^{b}$ & $1.47 \pm 0.19^{b}$ & $0.73 \pm 0.06^{b}$ \\
\hline & INV & $14.5 \pm 3.10^{a}$ & $2.75 \pm 0.50^{b c}$ & $0.89 \pm 0.13^{b}$ & $0.86 \pm 0.19^{b}$ & $0.53 \pm 0.1^{b}$ \\
\hline \multirow{2}{*}{ Ligustrum lucidum } & NAT & $65.4 \pm 63.66^{a}$ & $1.8 \pm 1.30^{\mathrm{ab}}$ & $0.12 \pm 0.19^{a}$ & $0.11 \pm 0.18^{a}$ & $0.07 \pm 0.12^{\mathrm{a}}$ \\
\hline & INV & $26.4 \pm 27.98^{a}$ & $1 \pm 0.70^{a}$ & $0.14 \pm 0.30^{b}$ & $0.13 \pm 0.30^{a}$ & $0.06 \pm 0.13^{\mathrm{a}}$ \\
\hline \multicolumn{7}{|c|}{ ANOVA results } \\
\hline \multicolumn{2}{|c|}{ host species } & ns & $*$ & $* *$ & ** & ** \\
\hline \multicolumn{2}{|c|}{ inoculum source } & ns & $*$ & $*$ & ns & ns \\
\hline \multicolumn{2}{|c|}{ host species*inoculum } & ns & ns & $*$ & ns & ns \\
\hline
\end{tabular}


INV soil. Thus, the establishment of exotic species might interfere in the linkages between native host species and AMF. Stinson et al. (2006) previously reported this strategy of invasion for Alliaria petiolata, a European invasive species of North American forests.

Soil changes caused by the invasive species can alter the relationship between the microbiota and the native host species, negatively affecting its growth and favoring the invasion (Hawkes et al. 2006). This mechanism may explain the negative value of mycorrhizal dependence observed in this study in C. tala plants inoculated with invaded forest soil. In this treatment, the negative effect on growth may be due to the symbiosis located at the parasitic extreme of the mutualism-parasitism-continuum, according to the model proposed by Johnson \& Graham (2013). This could be a key factor for the establishment of L. lucidum in $C$. tala forests, which may hamper the regeneration of the native species in the invaded areas.

We recorded twelve species of Glomeromycota from the pots. Four out of the seven AMF species identified in the NAT inoculum were found in the pots: $D$. spurca and Pacispora sp. 1 in C. tala pots, Glomus sp. in L. lucidum pots, and A. delicata in both treatments. Similarly, three out of the six species present in the INV inoculum were recovered after the bioassay: $S$. sinuosa in C. tala pots, Glomus sp. in L. lucidum pots, and A. delicata in both treatments. On the other hand, spores of Acaulospora sp., C. claroideum, C. etunicatum, F. coronatum, Pacispora sp. 1, and S. constrictum were recovered from the pots although they had not been found in the inocula. These results indicate that $C$. tala and L. lucidum are favorable hosts and that they promote the sporulation of different AMF species.

Acaulospora delicata was the only species present in all treatments, whereas the rest of the species were specific to each treatment. In the case of $C$. tala, Acaulospora sp., D. spurca, C. claroideum, F. coronatum, Pacispora sp. 1 were found in the pots inoculated with NAT soil, whereas Pacispora sp. 2, S. sinuosa, and Scutellospora sp.1 were observed in those inoculated with the INV soil. With regard to L. lucidum, C. etunicatum was present exclusively in the pots with NAT soil, while Glomus sp. was found in both treatments. Pots of C. tala showed the presence of six families (Acaulosporaceae, Glomeraceae, Claroideoglomeraceae, Diversisporaceae, Pacisporaceae, and Gigasporaceae), while pots of L. lucidum had only Acaulosporaceae, Glomeraceae, and Claroideoglomeraceae. Therefore, it is important to note that L. lucidum showed a smaller number of families than C. tala. In addition, pots of $C$. tala inoculated with both sources of inoculum had a greater richness and diversity of Glomeromycota than L. lucidum. The richness found in C. tala pots could indicate that this native tree tends to promote the development of a greater variety of AMF species than the exotic one. However, this result does not allow us to establish a direct relationship between the diversity of spores and the percentages of colonization observed, because L. lucidum showed the highest colonization. Besides, we should consider that the AMF species found are not necessarily the same species colonizing the roots (Fernández Bidondo et al. 2018 and reference therein). Although we were not able to identify the mechanisms underlying the AMF-host interaction for the plant species studied, we can confirm that these species interact with AMF in a different way, which was reflected in both the values of mycorrhizal dependence and the colonization percentages.

It is interesting to mention that the $\mathrm{AMF}$ species recovered from L. lucidum pots belong to the families Acaulosporaceae, Claroideoglomeraceae, and Glomeraceae. These families are commonly found in disturbed environments, which suggests great adaptability, probably due to low host specificity and great tolerance to abiotic stresses (Chagnon 2013; Asmelash 2016). Furthermore, Claroideoglomus etunicatum is one of the most widely distributed species of AMF and has been registered in diverse ecosystems including Alaska and Namibia (http://invam.caf.wvu.edu). Although these results are insufficient to conclude that $L$. lucidum tends to relate to generalist and cosmopolitan AMF species, as suggested by Núñez \& Dickie (2014), it would be interesting to conduct new studies to explore this hypothesis.

The PCA considering the relative abundance of AMF species grouped the samples by both plant species and source of inoculum, although the type of host was the factor that contributed the most to this separation. This indicates that there were differences in the diversity of fungal propagules between sites and in the AMF species with which each plant species establishes the symbiosis. Our results are in agreement with the laboratory tests of Bever et al. (1996) and Leal et al. (2009), who found that the AMF diversity was more related to the host species than to the source of inoculum.

In our study, the growth parameters of $C$. tala and L. lucidum showed no differences between treatments. However, we cannot rule out that mycorrhization influences plant fitness under field conditions at other developmental stages not evaluated herein (i.e., germination, flowering, fruit production).

Our results suggest that the invasion of the exotic L. lucidum in C. tala forests may be acting as a factor that determines changes in the diversity of AMF and affects the mutualism relationships that occur between native plants and these fungi. Therefore, we confirm the initial hypothesis of this study, that L. lucidum establishes mutualisms with some AMF species from the talares and its spread tends to modify the fungal community and pre-existent interactions between native plants and fungi. Although future studies that deepen the understanding of these interactions are required, this work contributes to the understanding of the mechanisms that operate in the invasion phenomena, demonstrating that AMF can play a role in this process, not only benefiting the invasive species but also preventing the regeneration of native plants. 


\section{References}

Asmelash F, Bekele T, Birhane E. 2016. The potential role of arbuscular mycorrhizal fungi in the restoration of degraded lands. Frontiers in Microbiology 7: 1095. doi: 10.3389/fmicb.2016.01095

Bever JD, Morton JB, Antonovics J, Schultz PA. 1996. Host-de-pendent sporulation and species diversity of arbuscular mycor-rhizal fungi in a mown grassland. Journal of Ecology 84: 71-82.

Błaszkowski J. 2012. Glomeromycota. Kraków, Władysław: Szafer Institute of Botany, Polish Academy of Sciences.

Brundrett MC. 2009. Mycorrhizal associations and other means of nutrition of vascular plants: Understanding the global diversity of host plants by resolving conflicting information and developing reliable means of diagnosis. Plant Soil 320: 37-77.

Cabello MN, Albanesi A, Brandan C. 2013. Control de calidad de inoculantes formulados con hongos micorrícicos arbusculares (HMA). In: Albanesi A, Benintende S, Cassán F, Perticari A. (eds.) Manual de procedimientos microbiológicos para la evaluación de inoculantes. Buenos Aires, REDCAI -DIMAyA-Asociación Argentina de Microbiología. p. 45-54.

Chagnon PL, Bradley RL, Maherali H, Klironomos JN. 2013. A trait-based framework to understand life history of mycorrhizal fungi. Trends in Plant Science 18: 484-491.

Checinska Sielaff A, Polley HW, Fuentes-Ramirez A, Hofmockel K, Wilsey BJ. 2019. Mycorrhizal colonization and its relationship with plant performance differs between exotic and native grassland plant species. Biological Invasions 21: 1981-1991.

Fernández Bidondo ML, Colombo RP, Recchi M, et al. 2018. Detection of arbuscular mycorrhizal fungi associated with pecan (Carya illinoinensis) trees by molecular and morphological approaches. MycoKeys 42: 73 . doi: $10.3897 /$ mycokeys.42.26118

Dascanio LM, Ricci SE. 1988. Descripción florístico-estructural de fisonomías dominadas por árboles en la reserva integral de Punta Lara (Pcia. de Buenos Aires, República Argentina). Revista del Museo de La Plata 14: 191-206.

Dascanio LM, Barrera MD, Frangi JL. 1994. Biomass structure and dry matter dynamics of subtropical alluvial and exotic Ligustrum forests at the Río de la Plata, Argentina. Vegetatio 115: 61-76.

Deguchi S, Uozumi S, Touno E, Kaneko M, Tawaraya K. 2012. Arbuscular mycorrhizal colonization increases phosphorus uptake and growth of corn in a white clover living mulch system. Journal of Soil Science and Plant Nutritionis 58: 169-172.

Di Rienzo JA, Casanoves F, Balzarini MG, Gonzalez L, Tablada M, Robledo CW. 2016. InfoStat versión 2016. Grupo InfoStat, FCA, Universidad Nacional de Córdoba, Argentina. 2016. http://www. infostat.com. ar. 10 Jun. 2020.

Gerdemann JW, Nicolson TH. 1973. Spores of mycorrhizal Endogone species stracted from soil by west sieving and decanting. Transactions of the British Mycological Society 46: 235-239.

Grilli G, Urcelay C, Longo MS, Galetto L. 2014. Mycorrhizal fungi affect plant growth: experimental evidence comparing native and invasive hosts in the context of forest fragmentation. Journal of Plant Ecology 215: 1513-1525.

Gross N, Le Bagousse-Pinguet Y, Liancourt P, Urcelay C, Catherine R, Lavorel S. 2010. Trait-mediated effect of arbuscular mycorrhiza on the competitive effect and response of a monopolistic species. Functional Ecology 24: 1122-1132.

Hawkes CV, Belnap J, D’Antonio C, Firestone MK. 2006. Arbuscular mycorrhizal assemblages in native plant roots change in the presence of invasive exotic grasses. Plant and Soil 281: 369-380.

Irrazabal G. 2007. Estudio de las comunidades de hongos formadores de micorrizas arbusculares en bosques nativos de Celtis tala. PhD Thesis, Universidad Nacional de La Plata, La Plata.
Johnson NC, Graham JH. 2013. The continuum concept remains a useful framework for studying mycorrhizal functioning. Plant and Soil 363: 411-419.

Klironomos J, Zobel M, Tibbett M, et al. 2011. Forces that structure plant communities: quantifying the importance of the mycorrhizal symbiosis. New Phytologist 189: 366-370.

Koorem K, Saks U, Sober V, et al. 2012. Effects of arbuscular mycorrhiza on community composition and seedling recruitment in temperate forest understory. Basic and Applied Ecology 13: 663-672.

Leal PL, Stürmer SL, Siqueira JO. 2009. Occurrence and diversity of arbuscular mycorrhizal fungi in trap cultures from soils under different land use systems in the Amazon, Brazil. Brazilian Journal of Microbiology 40: 111-121.

McCain KNS, Wilson GWT, Blair JM. 2011. Mycorrhizal suppression alters plant productivity and forb establishment in a grass-dominated prairie restoration. Plant Ecology 212: 1675-1685.

McCune B, Mefford MJ. 2006. PC-ORD, version 5.0, Multivariate analysis of ecological data. Glaneden Beach, MjM Solfware Desing.

Nuñez MA, Dickie IA. 2014. Invasive belowground mutualists of woody plants. Biological Invasions 16: 645-661.

Phillips JM, Hayman DS. 1970. Improved procedure for clearing root and staining parasitic and VA-mycorrhizal fungi for rapid assessment of infection. Transactions of the British Mycological Society 55: 158-161.

Piper CL, Siciliano SD, Winsley T, Lamb EG. 2015. Smooth brome invasion increases rare soil bacterial species prevalence, bacterial species richness and evenness. Journal of Ecology 103: 386-396.

Sánchez O, Ferrer J, Duymovich O, Hurtado A. 1976. Estudio pedológico integral de los Partidos de Magdalena y Brandsen (Prov. de Bs. As.). Anales de Laboratorio de Entrenamiento Multidisciplinario para la Investigación Tecnológica (LEMIT) 310: 1-119.

Smith SE, Read DJ. 2008. Mycorrhizal symbiosis. New York, NY, Academic Press.

Stinson KA, Campbell SA, Powell JR, et al. 2006. Invasive plant suppresses the growth of native tree seedlings by disrupting belowground mutualisms. PLOS Biology 4: e140. doi: 10.1371/journal.pbio.0040140

Vargas Gil J, Scoppa CO, Iñiguez A. 1972. Génesis de los suelos de la región norte de la Bahía de Samborombón. Revista de Investigaciones Agropecuarias (INTA) 9: 29-52.

Velázquez MS. 2011. Comunidades de hongos formadores de micorrizas arbusculares en el Parque Nacional El Palmar. PhD Thesis, Universidad Nacional de La Plata, La Plata.

Vervoorst F. 1967. Las comunidades vegetales de la depresión del Salado (Provincia de Buenos Aires). Buenos Aires, Instituto Nacional de Tecnologia Agropecuaria (INTA).

Walker C, Myze W, McNabb HS. 1982. Populations of endogenous fungi at two populations in Cental Iowa. Canadian Journal of Botany 60: 2518-2529.

Wang CY, Xiao HG, Zhao LL, et al. 2016. The allelopathic effects of invasive plant Solidago canadensis on seed germination and growth of Lactuca sativa enhanced by different types of acid deposition. Ecotoxicology 25: 555-562.

Xiao HF, Feng YL, Schaefer DA, Yang XD. 2014. Soil fungi rather than bacteria were modified by invasive plants, and that benefited invasive plant growth. Plant and Soil 378: 253-264.

Zamora Nasca L, Montti L, Grau R, Paolini L. 2014. Efectos de la invasión del ligustro, Ligustrum lucidum, en la dinámica hídrica de las Yungas del noroeste Argentino. Bosque 35: 195-205.

Zhang Q, Yang R, Tang J, Yang H, Hu S, Chen X. 2010. Positive feedback between mycorrhizal fungi and plants influences plant invasion success and resistance to invasion. PLOS ONE 5: e12380. doi: 10.1371/ journal.pone. 0012380

Zubek S, Majewska ML, Błaszkowski J, Stefanowicz AM, Nobis M, Kapusta P. 2016. Invasive plants affect arbuscular mycorrhizal fungi abundance and species richness as well as the performance of native plants grown in invaded soils. Biology and Fertility of Soils 52: 879-893. 